INTERNATIONAL HIGHER EDUCATION, Number 72. Summer 2013

Pages 12-13

\title{
Are Global Rankings Unfair to Latin American Universities? ANDRÉS BERNASCONI
}

\begin{abstract}
Andrés Bernasconi is a professor of higher education at the School of Education of the Pontificia Universidad Católica de Chile. E-mail: abernasconi@uc.cl.
\end{abstract}

In its 2012 edition, the Times Higher Education World University Ranking put no Latin American university in the group of the best 100, and only four among the entire cast of 400. The Shanghai 2012 ranking treats Latin America no better: one in the leading group of 150 and 10 in the overall group of 500 universities ranked.

This status is somewhat puzzling, given that Brazil is the 6th economy in the world and Mexico the 14th. This should make a difference when it comes to the possibility of supporting fine institutions of higher education, as one finds in countries such as Israel, with 3 institutions in the top 100 in the Chinese ranking; or the Netherlands, with 2.

University leaders in Latin America do feel there is something wrong in the rankings, arguing that they are biased and unfair to the region and that Latin American universities are essentially different from the concept of a university implied by the rankings. 


\section{The Problem Is the Rankings}

A group of Latin American university leaders met in Mexico in May, 2012, backed by UNESCO (United Nations Educational, Scientific, and Cultural Organization), to discuss rankings and what to do about them. It was concluded that rankings are invalid measurements of university performance-both in their composite index and with respect to every variable purported to measure. Another conclusion was that rankings are particularly unfit to recognize Latin America's universities-"responsibilities and functions that transcend the more traditional ones of Anglo-Saxon universities, which serve as standards for the rankings." The rectors also noted that this bias favoring the Anglo-Saxon model of the university is reinforced by the use of the ISI-Thomson Reuters and SCOPUS publication and citations databases, which collect material mostly published in English and "in the fields of health sciences and engineering."

Of course, Latin America is not the only region in the world with a valid claim against the biases of the rankings. Thus, Asia has at least as good a motive as in this part of the world to protest the unfairness of it all, perhaps even better than here: after all, Asians are much more numerous and are not even part of the hegemonic Western tradition. Nonetheless, most of the universities showing greatest progress in the rankings are located in Asia: Korea, Singapore, Taiwan, and China. Instead of complaining that no sufficient journals exist to publish their work in Korean or Chinese, scholars in that part of the world teach themselves English language and publish internationally in that language, as scholars do also in Israel and the Netherlands. 


\section{Latin American Universities ARE Different}

Now, what are these unique responsibilities and functions discharged by Latin American universities, which would recommend treating them differently from the model of the "Anglo-Saxon" university? Usually Latin American universities speak about their "social" mission, an elusive concept that is meant to encompass everything that universities supposedly do in here that is not research, or teaching, or transfer of research results, or indeed any of the functions associated with the university as an institution elsewhere in the world. The notion of a distinct "social" mission mostly seeks to capture the roles really or allegedly played by universities in fostering democracy, promoting social inclusion, or forging a national identity. Universities in Latin America have often played this role when democratic rule has broken down and only universities and few other institutions have remained as spaces of relative freedom and political organization. These have been worthy endeavors, certainly, but not exclusive of universities in the Latin American region. Moreover, as democratic governance and the rule of law consolidate in Latin America, universities are increasingly relieved of this subsidiary political role; and need instead to reconnect with their proper institutional function as centers of knowledge.

\section{Rankings As a Message to Latin America}

Criticism of rankings as a valid methodology to order universities on the basis of quality is well founded. But one needs not to agree with the proposition that university Num. 100 is "better" in any meaningful way than Num. 120, to listen 
to the message that research-based rankings keep sending year after year: Latin American higher education is nearly invisible to the world of research.

Yes, as the rectors claim, this is in part a problem of insufficient funding for science in Latin America. However, this issue is not the only one and not even the main one. There have been great increases in public money allocated to research since the 1990s in Brazil, Chile, and Mexico. Publications have multiplied in response, but not at a rate that would make any difference globally. The two key resources lacking in Latin American universities are a large enough numbers of dedicated research faculty and good governance.

Most of the finest universities in Latin America (with the exception of Brazil's top few) still have academic staffs in which PhD holders are a minority of the faculty and where fluency in languages, other than Spanish and Portuguese, is still exceptional (and Brazil is no different here). Moreover, many researchtrained academics in the region have salaries so low that they need to have a second job to make ends meet. No internationally competitive research performance can be expected of faculty not trained to carry out research, by researchers who are distracted by financial insecurity, or from academics whose entire knowledge base is published in Spanish and Portuguese.

The second major roadblock is the governance of institutions and the steering of the national higher education systems. University autonomy, an object of quasi-religious attachment in Latin America, served for decades the noble function of keeping corrupt, incompetent, loony, or autocratic governments off the backs of universities. Sadly, in some countries, that function of autonomy continues to be necessary today. However, in most of the region, stable democracies with reasonable leadership are consolidating a space of 
civilized dialogue in which universities can afford, at low risk to their prerogatives, to allow more policymaking in higher education on the part of elected officials, rather than slamming the door of autonomy in their faces. This is important because most Latin American universities, especially in the public sector, do not have the quality leadership or the internal political platform to reform themselves. Therefore, they need to work with their governments (as universities increasingly do in Europe, Australia, and Asia) to find new strategies and mechanisms to change. And change is sorely needed in several key dimensions: academic cadres have to be renovated, research money has to be directed to those who can use it productively, and career structures and salary schedules for professors have to be redesigned. In the area of administration, reform is needed to introduce long-term, strategic decision making in universities, curb administrative bloat, and limit the deleterious effect of partisan politics upon university affairs. Such changes may usher a new era for Latin America's universities, one where research-based rankings may feel less alien to them. 